Marquette University

e-Publications@Marquette

College of Nursing Faculty Research and

Publications

Nursing, College of

3-2-2017

\title{
Development of a Self-Management Theory-Guided Discharge Intervention for Parents of Hospitalized Children
}

\author{
Kathleen Sawin \\ University of Wisconsin - Milwaukee \\ Marianne Weiss \\ Marquette University, marianne.weiss@marquette.edu \\ Norah L. Johnson \\ Marquette University, norah.johnson@marquette.edu \\ Karen Gralton \\ Children's Hospital of Wisconsin \\ Shelly Malin \\ Marquette University
}

See next page for additional authors

Follow this and additional works at: https://epublications.marquette.edu/nursing_fac

Part of the Nursing Commons

\section{Recommended Citation}

Sawin, Kathleen; Weiss, Marianne; Johnson, Norah L.; Gralton, Karen; Malin, Shelly; Klingbeil, Carol; Lerret, Stacee M.; Thompson, Jamie J.; Zimmanck, Kim; Kaul, Molly; and Schiffman, Rachel, "Development of a Self-Management Theory-Guided Discharge Intervention for Parents of Hospitalized Children" (2017). College of Nursing Faculty Research and Publications. 527.

https://epublications.marquette.edu/nursing_fac/527 


\section{Authors}

Kathleen Sawin, Marianne Weiss, Norah L. Johnson, Karen Gralton, Shelly Malin, Carol Klingbeil, Stacee M. Lerret, Jamie J. Thompson, Kim Zimmanck, Molly Kaul, and Rachel Schiffman 


\section{Marquette University \\ e-Publications@Marquette}

\section{Nursing Faculty Research and Publications/College of Nursing}

This paper is NOT THE PUBLISHED VERSION; but the author's final, peer-reviewed manuscript. The published version may be accessed by following the link in the citation below.

Journal of Nursing Scholarship, Vol. 49, No. 2 (2017): 202-213. DOI. This article is (C) Wiley and permission has been granted for this version to appear in e-Publications@Marquette. Wiley does not grant permission for this article to be further copied/distributed or hosted elsewhere without the express permission from Wiley.

\section{Contents}

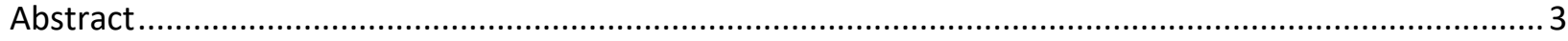

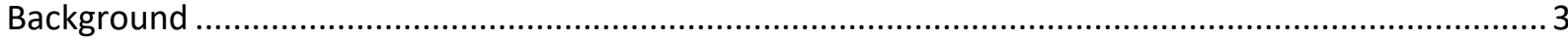

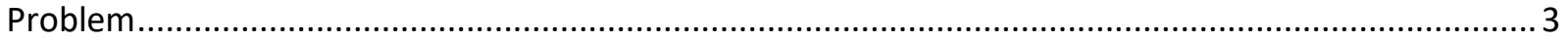

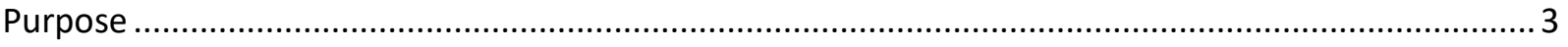

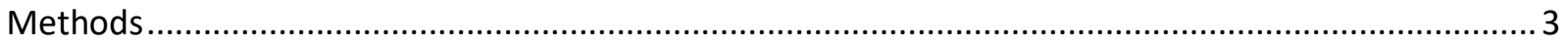

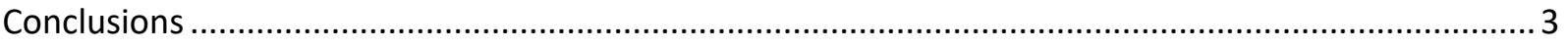

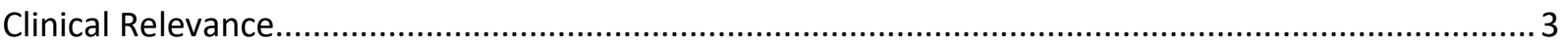

Theoretical and Methodological Influences on Intervention Development .......................................... 5

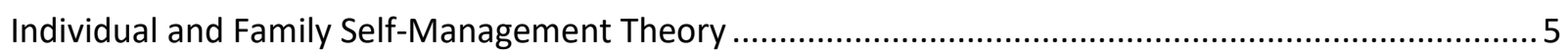

Model of Clinical Judgment in Nursing: The Reflective Practitioner .................................................. 6

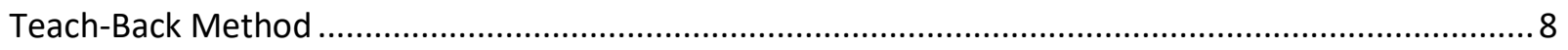

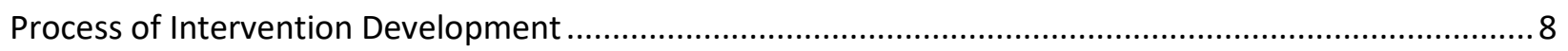

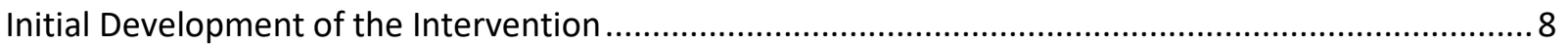

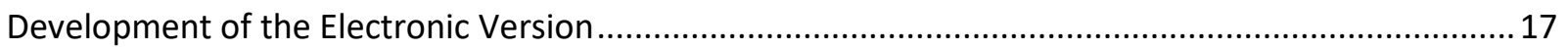

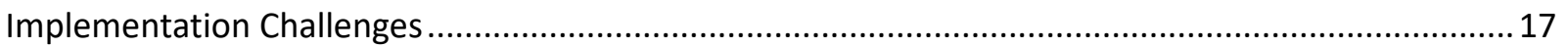

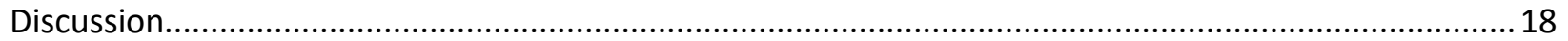

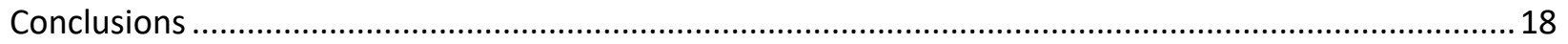

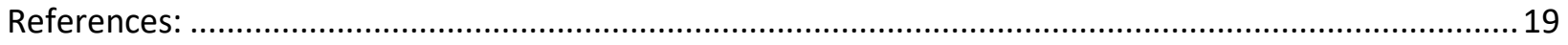




\section{Development of a Self-Management Theory-Guided Discharge Intervention for Parents of Hospitalized Children}

Kathleen J. Sawin

College of Nursing, University of Wisconsin-Milwaukee, Milwaukee, WI

Children's Hospital of Wisconsin, Milwaukee, WI

Marianne E. Weiss

Wheaton Franciscan Healthcare- St. Joseph/Sister Rosalie Klein, Marquette University, Milwaukee, WI

Norah Johnson

College of Nursing, Marquette University, Milwaukee, WI

Karen Gralton

Children's Hospital, Milwaukee, WI

College of Nursing, University of Wisconsin-Milwaukee, Milwaukee, WI

Shelly Malin

Mennonite College of Nursing, Illinois State University, Normal, IL

Carol Klingbeil

College of Nursing, University of Wisconsin-Milwaukee, Milwaukee, WI

Stacee M. Lerret

Medical College of Wisconsin, Milwaukee, WI

Children's Hospital of Wisconsin, Milwaukee, WI

Jamie J. Thompson

Milwaukee Public School System, Milwaukee, WI

Kim Zimmanck

Children's Hospital of Wisconsin, Milwaukee, WI

Molly Kaul

Children's Hospital of Wisconsin, Milwaukee, WI

Rachel F. Schiffman

Self-Management Science Center, University of Wisconsin-Milwaukee, Milwaukee, WI College of Nursing, University of Wisconsin-Milwaukee, Milwaukee, WI 
Abstract

Background

Parents of hospitalized children, especially parents of children with complex and chronic health conditions, report not being adequately prepared for self-management of their child's care at home after discharge.

Problem

No theory-based discharge intervention exists to guide pediatric nurses' preparation of parents for discharge.

\section{Purpose}

To develop a theory-based conversation guide to optimize nurses' preparation of parents for discharge and self-management of their child at home following hospitalization.

\section{Methods}

Two frameworks and one method influenced the development of the intervention: the Individual and Family Self-Management Theory, Tanner's Model of Clinical Judgment, and the Teach-Back method. A team of nurse scientists, nursing leaders, nurse administrators, and clinical nurses developed and field tested the electronic version of a nine-domain conversation guide for use in acute care pediatric hospitals.

\section{Conclusions}

The theory-based intervention operationalized self-management concepts, added components of nursing clinical judgment, and integrated the Teach-Back method.

\section{Clinical Relevance}

Development of a theory-based intervention, the translation of theoretical knowledge to clinical innovation, is an important step toward testing the effectiveness of the theory in guiding clinical practice. Clinical nurses will establish the practice relevance through future use and refinement of the intervention.

The transition to home-based recovery and continuing management of health needs can be challenging when hospitalized children and their families are not adequately prepared for discharge (Weiss et al., 2008). Many parents report feeling overwhelmed and underprepared for their role in managing their child's care at home within the context of family and work demands (Berry et al., 2011; Lerret \& Weiss, 2011; Lerret et al., 2014). Parental concerns about the health of the child at discharge, as well as worry about and difficulty coping with postdischarge health problems, can lead to unplanned utilization of healthcare resources such as unscheduled office visits, emergency department (ED) visits, and readmission to the hospital (Bernstein et al., 2002; Berry, Agrawal, Cohen, \& Kuo, 2013; Weiss et al., 2008; Weiss, Ryan, \& Lokken, 2006).

Discharge preparation is multifaceted, encompassing inter-related processes of discharge planning, coordination of postdischarge services, and discharge teaching (Weiss et al., 2015). 
Discharge teaching includes both structured and informal education that ideally begins on admission and culminates with a confirmation on the day of discharge that the child and family are knowledgeable and ready to carry out each component of the plan for care at home after discharge (Berry et al., 2014; Kornburger, Gibson, Sadowski, Maletta, \& Klingbeil, 2013). While understanding of the disease process and treatment plans are important, discharge teaching often does not adequately address the broad range of planning, coping skills, and supports needed for the many competing demands on family resources that factor into child and parent self-management at home (Lerret et al., 2014).

While comprehensive discharge preparation is important for all families (Berry et al., 2014), it is particularly critical for children with complex or chronic medical conditions (Lerret \& Weiss, 2011; Lerret et al., 2014). These children often have frequent hospitalizations and can account for a substantial number of readmissions and healthcare costs (Berry et al., 2011). The child's health outcomes in the postdischarge period can be compromised when preparation for discharge is not comprehensively planned (Desai, Popalisky, Simon, \& Mangione-Smith, 2015). For example, parents of children who had a solid organ transplant reported needing emotional support and guidance in parenting the child in addition to education about the condition and medication administration skills (Lerret et al., 2014). These findings point to the need for better understanding of the optimal communication content, process, and timing in discharge interventions (Samuels-Kalow, Stack, \& Porter, 2012).

Comprehensive discharge interventions for adult patients have emerged to support effective hospital discharge and transition to home (Hansen et al., 2013), but are less developed in pediatric hospitals. In a recent review of 14 pediatric intervention studies (asthma, cancer, and neonatal care), 6 were effective at reducing at least one outcome (ED or hospital readmission). Four of the six had a robust inpatient education component, four had a follow-up community component, and all used some type of individualized planning with patients and families. However, none reported a conceptual framework or detail outlining what components of the intervention were successful (Auger, Kenyon, Feudtner, \& Davis, 2014). The researchers recommended measuring the extent to which patients and parents feel prepared for selfmanagement upon discharge as a useful outcome to evaluate quality of discharge care. A recently published Framework for Pediatric Hospital Discharge Care provides guidelines for family-centered discharge processes and concurs that discharge readiness is the culmination of the discharge care process (Berry et al., 2014).

Nursing scientists have strongly advocated for theory-based interventions as a mechanism to increase quality and reproducibility of findings (Conn \& Groves, 2011; Kazer, Bailey, \& Whittermore, 2010; Sidani \& Braden, 2011). However, currently there are no theory-based nursing discharge interventions in the nursing literature. Using a theory as the foundation for development of an intervention guides selection of operational components of the intervention. Linking theoretical constructs, measurement of outcomes, and interpretation of the results in light of existing knowledge embedded in the theory provides an understanding of how the intervention works to achieve the desired goals (Conn \& Groves, 2011). 
This article addresses the gap in theory-based pediatric discharge preparation literature by detailing the development of a clinical nurse-delivered intervention built by a team of nurse scientists, clinical leaders, administrators, and clinical nurses practicing in an acute care pediatric hospital. This Family Self-Management Discharge Preparation Intervention (FSM-DPI), a conversation guide designed to optimize discharge preparation for parents of hospitalized children, was influenced by the Individual and Family Self-Management Theory (IFSMT; Ryan \& Sawin, 2009), Tanner's Model of Clinical Judgment in Nursing (Tanner, 2006), and the TeachBack method aimed at improving patient comprehension of health teaching (Schillinger et al., 2003).

The IFSMT was used to identify and organize the self-management content (the what) of the intervention, which focused on enhancing parental self-management at home. The Model of Clinical Judgment in Nursing was used to structure each of the intervention content areas in a way that facilitated aspects of nursing clinical judgment (the why), and the Teach-Back method was used to suggest how the nurse might address each self-management domain (the how). A short description of each will be presented followed by the specific process of developing the pediatric discharge intervention.

\section{Theoretical and Methodological Influences on Intervention Development}

\section{Individual and Family Self-Management Theory}

The IFSMT (Figure 1) is a midrange theory that describes the relationship of concepts in the context and process domains with the proximal (self-management behaviors) and ultimately distal outcomes (health status, quality of life, and cost of health; Ryan \& Sawin, 2009). Selfmanagement places the accountability for managing a condition with the individual and/or family and thus changes the focus of care. Concepts in the context domain describe the unique risk and protective factors that will impact the family's ability to carry out self-management. These concepts are divided into three categories: (a) the complexity of the child's condition, (b) the child's physical and social environment, and (c) individual child and family factors. 


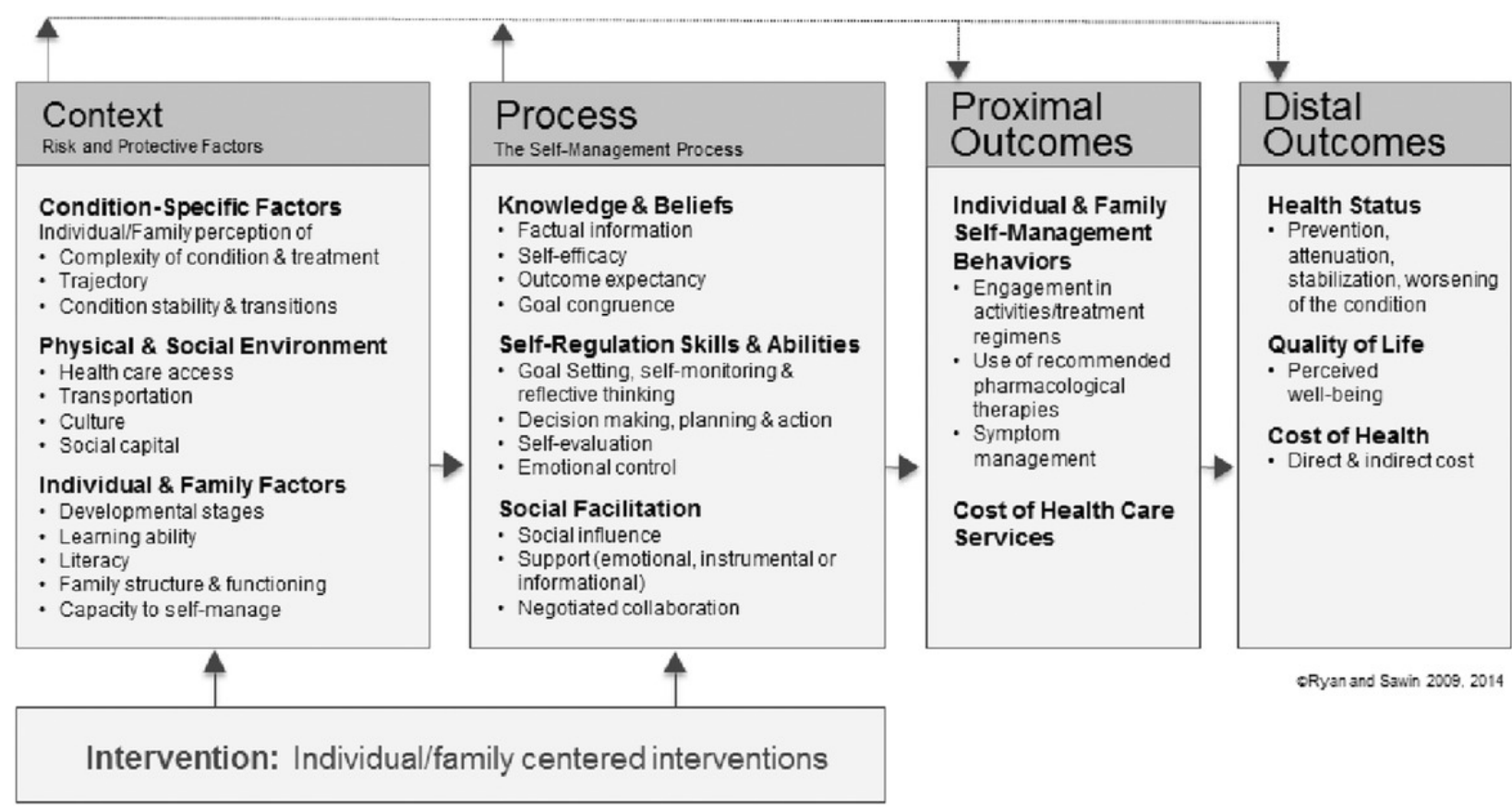

Figure 1. Individual and Family Self-Management Theory

The concepts in the process domain of the IFSMT capture the child's and parent's learning and the process of developing competency in self-management skills and abilities. These concepts delineate the three categories in the self-management process: (a) knowledge and beliefs, (b) self-regulation, and (c) social facilitation. Learning about the condition prepares the family members to resolve competing goals and develop confidence in their ability to manage a condition. Self-regulation is an iterative problem-solving process and includes a number of skills and abilities such as goal setting, self-monitoring, decision making, planning, and selfevaluation. Both the child and the parent develop skills to deal with the emerging issues. For example, the child or the parent may need to learn the difference between a minor symptom that can be evaluated with a "watch and see" approach and a symptom that needs immediate action. Developing plans and continuous evaluation of the effectiveness of those plans is critical to the process. Emotional adjustments are often a challenging aspect of self-regulation that change throughout development as well as disease progression. Social facilitation provided by healthcare providers, family members, and peers aide the parent in gaining these abilities and skills.

\section{Model of Clinical Judgment in Nursing: The Reflective Practitioner}

Tanner's Model of Clinical Judgment in Nursing, or "thinking like a nurse," is a type of engaged moral reasoning. This model, generated from an extensive review of over 200 studies on clinical judgment in nursing, expands the understanding of the complexity of nurses' clinical judgments when caring for a child/family and the perception of what constitutes exquisite care (Tanner, 2006). The model reflects the impact of the nurse's skill, knowledge, pattern recognition, and expectations on the clinical interaction. Knowing the child's objective data and the child or 
family concerns is foundational but not sufficient for reflective clinical judgment. Clinical judgment requires not only integration of the parent's or family's complexity, but the nurse's consideration of the complexity of the context of care, including knowledge of the clinical environment and the competing demands of nurse and parent. Tanner describes the process that experienced nurses use as (a) noticing: developing a perception of the situation; (b) interpreting: developing an understanding of the situation; (c) responding: implementing the best course of action for the situation; and (d) reflecting: evaluating the health status and the child or family to determine whether or not the action needs to be revised (Table 1).

Table 1. The Impact of the Research-Based Model of Clinical Judgment on the Development of the Intervention

\section{Tanner findings in synthesis of the literature}

Clinical judgments are often influenced as much by what nurses bring to the situation (expectations, knowledge, and pattern recognition) than the objective data encountered. Knowledge of the patient is necessary but not enough for sound clinical judgment.

Engaging with the parents and their concerns is necessary, as is an engagement with the child and his or her concerns.

Clinical judgments are complex and are based in the context of the patient/family and the culture of the nursing care unit. They reflect analytic, intuitive and narrative reasoning patterns.

Nurse engagement in reflection improves learning, expands clinical knowledge, and enhances judgment in complex situations.

Aspects of the process of clinical
judgment
Noticing
A perceptual grasp of the
situation at hand
Noticing emerges from
(a) nurses' expectations of the
situation, which in turn are built
on nurses' knowledge of
patient's patterns;
(b) nurses' experience with and
clinical knowledge of like
patients, and nurses' scientific
knowledge. This stage is where
nurses get their initial grasp of
the situation.
Interpreting/responding
Nurses' noticing and initial
interpretation or grasp of the
clinical situation triggers a
reasoning pattern and decision
on a course of action.

\section{Reflection}

Reflection in action is the nurses ability to "read" how the patient/family is responding to the nursing intervention and adjust the interventions based on that assessment.
Translation to the intervention

The prompt statements in the intervention facilitate the nurses "noticing" areas that need to be addressed for successful discharge preparation.
The intervention structure delineates the nurses' interpretation of family preparation, specifically the nurses' assessment of whether the parent has the correct information/plan, incorrect information/incomplete plan, or no understanding or plan for the discharge component.

The intervention conversation guide is built on the assumption that the nurses' ability to read how the parent is responding to the intervention and adjust activities accordingly is the key to effective discharge preparation.

Note. Adapted from Tanner, C. A. (2006). Thinking like a nurse: A research-based model of clinical judgment in nursing. Journal of Nursing Education, 45(6), 204-211. 
The Teach-Back method emerged from the health literacy literature (Schillinger et al., 2003), which addressed an individual's ability to obtain and understand health information (Kemp, Floyd, McCord-Duncan, \& Lang, 2008; National Quality Forum, 2009; Peter et al., 2015). The Teach-Back method was established with the goals of improving the patients' understanding of their condition, verifying knowledge acquisition, and improving health outcomes (National Quality Forum, 2009). In the Teach-Back method, patients are asked to say back in their own words or "show" through demonstration, the knowledge and skills they have learned from their healthcare provider. It is a way to confirm patients' understanding and ability to apply health information and newly learned skills to manage their health needs. Key tenets of the method include using open-ended questions; grouping information provided into small segments; and checking, clarifying, and rechecking accuracy and completeness of learning. The method has been taught to numerous nurses, therapists, pharmacists, and other interdisciplinary healthcare providers across settings and has been implemented in the healthcare setting for which the discharge preparation intervention was created (Kornburger et al., 2013). While often used in practice, there is limited research on the Teach-Back method. A few researchers have found it to be effective in a range of patient teaching situations (Kemp et al., 2008; Peter et al., 2015; Slater, Dalawari, \& Huang, 2013; White, Garbez, Carroll, Brinker, \& Howie-Esquivel, 2013). Researchers have suggested that using the Teach-Back method helps patients transition from having their conditions managed by healthcare providers to becoming better able to selfmanage their condition (Haney \& Shepherd, 2013; Howie-Esquivel, White, Carroll, \& Brinker, 2011). Shifting the focus of discharge preparation from a nurse-to-parent information transfer session to a more interactive process was central to including this method in the intervention. Building and supporting family self-management capacity could improve parent and child outcomes following discharge.

\section{Process of Intervention Development}

\section{Initial Development of the Intervention}

\section{Collaborators from a clinical academic partnership, the Consortium for Pediatric Nursing} Research in Milwaukee, Wisconsin, which included the Children's Hospital of Wisconsin and the Colleges of Nursing at the University of Wisconsin-Milwaukee (UWM) and Marquette University, entered into a dialog to identify a research project of joint interest. Discharge teaching emerged as the priority due to the realities of the clinical environment and current practice, the strategic initiatives of the clinical organization, the expertise of investigators at Marquette University on discharge readiness, and the expertise of investigators at UWM in selfmanagement. The goal of the collaboration was to improve the pediatric discharge process with a nursing intervention. The intervention was aimed at improving the quality of discharge teaching, readiness for discharge, and coping in the postdischarge period by assuring that parents have the necessary self-management knowledge, skills, and abilities to transition to home self-management after a child's hospitalization. 
The identification of the problem and the outcomes was consistent with the IFSMT, which delineates, in the process domain, the skills and abilities needed to perform self-management behaviors. The self-management behaviors are proposed to impact child health, individual and family quality of life, and costs of health. Each of the self-management skills and abilities is amenable to change.

Having identified the problem and the expected outcomes, the investigators developed the goals, components of the intervention, model of delivery, and dose (Sidani \& Braden, 2011). The investigators recognized that assessments and interventions are carried out throughout the hospitalization, culminating in the child/parent being ready to self-manage the child's care following hospital discharge. The intervention was designed to be used as a single conversation guide, as a "day of discharge" verification of adequacy of family preparation for selfmanagement after discharge, with additional areas of inadequate preparation identified by the nurse. The patient population for this intervention was identified as parents who were taking a child home after a hospitalization of at least 2 days. It was anticipated that the level of discharge preparation included in this intervention would not be necessary for those who were hospitalized for a shorter time period. The unique needs of parents of newborns, children in critical care units, or children discharged to home hospice were not addressed in the intervention. The intervention was therefore appropriate for all other parents of hospitalized children from 0 to 18 years of age who could speak sufficient English to participate in an interactive intervention without an interpreter.

Acknowledging the clinical judgment of the skilled pediatric clinical nurse, the wide variety of medical conditions, the unique needs of families, and the varying discharge needs, the team determined that a structured, but non-condition-specific "conversation guide" would be the most useful and effective intervention to enhance discharge preparation. The investigators' philosophical approach was one that aimed to enhance the already strong judgment of the clinical nurse (Tanner, 2006) by developing a conversation that operationalized the evidencebased components of self-management (Ryan \& Sawin, 2009).

The comprehensive approach to development of the FSM-DPI involved incorporating the theory-based approaches and review of the literature on discharge preparations, readiness for discharge, and discharge interventions. The IFSMT formed the basis for the content of the intervention. The key process components of knowledge and beliefs, self-regulation, and social facilitation were incorporated as appropriate into nine content domains of the FSM-DPI: home care, child's care, practice, medications, watching child, recovery, child development, family adjustments, and parent support. The intervention was designed to guide the nurse through evaluation of a series of self-management issues that parents may face at home; facilitate assessment of the family's strengths; validate knowledge, skills, and abilities for managing the child's care; and assist parents in anticipating and solving emerging self-management issues after discharge (Table 2). While the content was developed directly from the IFSMT, the clinical nurses "relabeled" the content domains using language that was more congruent with the language a nurse might use when talking to families. For example "monitoring," a component in the IFSMT self-regulation process, was labeled "watching child" by the clinical nurses in our 
partnership. Because the intervention guide was to be used for children with varying conditions and often with unique contextual factors, the integration of these context factors relied on the nurse's clinical judgment.

Table 2. Interactive Discharge Conversation Guide: Preparing Parents to Manage Care at Home (With Confidence)

\begin{tabular}{|c|c|c|c|c|}
\hline $\begin{array}{c}\text { IFSMT Process } \\
\text { Concept } \\
\text { Primary Teach-Bacl } \\
\text { Component }\end{array}$ & $\begin{array}{c}\text { Intervention } \\
\text { Category }\end{array}$ & Prompt Statement & RN Assessment & RN Response \\
\hline $\begin{array}{l}\text { Knowledge Talk- } \\
\text { back }\end{array}$ & Medications & $\begin{array}{l}\text { Let's talk about each } \\
\text { medication that your } \\
\text { child will take at home. } \\
\text { (Have parent read list } \\
\text { back and talk back.) } \\
\text { - } \quad \text { Name and } \\
\text { reason for } \\
\text { taking } \\
\text { Dose and side } \\
\text { effects } \\
\text { Time of } \\
\text { administration } \\
\text { (if PRN, when } \\
\text { will you give } \\
\text { it?) } \\
\text { After listening to you, I } \\
\text { think we also need to } \\
\text { talk about }\end{array}$ & $\begin{array}{l}\text { [ ] Verbalizes } \\
\text { correct } \\
\text { information } \\
\text { [ ] } \\
\text { Incorrect/unsure } \\
\text { about information } \\
\text { [ ] No } \\
\text { understanding of } \\
\text { information }\end{array}$ & $\begin{array}{l}\text { [ ] Positive } \\
\text { reinforcement } \\
\text { [ ] } \\
\text { Supplemental } \\
\text { information } \\
\text { [ ] Extensive } \\
\text { teaching } \\
\text { [ ] Corrected } \\
\text { information } \\
\text { errors } \\
\text { [ ] Provided } \\
\text { additional } \\
\text { resources }\end{array}$ \\
\hline $\begin{array}{l}\text { Knowledge/self- } \\
\text { efficacy Talk-back }\end{array}$ & Child's Care & $\begin{array}{l}\text { I am interested in } \\
\text { making sure you } \\
\text { are ready to take } \\
\text { your child home } \\
\text { from the hospital } \\
\text { What part of your } \\
\text { child's care do you } \\
\text { feel sure you can } \\
\text { handle? } \\
\text { What are the parts } \\
\text { of your child's care } \\
\text { that you don't feel } \\
\text { sure you can } \\
\text { handle? What } \\
\text { other information } \\
\text { can I get you? }\end{array}$ & $\begin{array}{l}\text { [ ] Verbalized correct } \\
\text { information } \\
\text { [ ] Incorrect/unsure about } \\
\text { information } \\
\text { [ ] No understanding of } \\
\text { information }\end{array}$ & $\begin{array}{l}\text { [ ] Provided positive } \\
\text { reinforcement } \\
\text { [ ] Provided } \\
\text { supplemental } \\
\text { information } \\
\text { [ ] Provided extensive } \\
\text { teaching } \\
\text { [ ] Corrected information } \\
\text { errors } \\
\text { [ ] Provided additional } \\
\text { resources }\end{array}$ \\
\hline
\end{tabular}




\begin{tabular}{|c|c|c|c|c|}
\hline & & $\begin{array}{l}\text { What worries or } \\
\text { concerns do you } \\
\text { have about caring } \\
\text { for your child at } \\
\text { home? } \\
\text { What other } \\
\text { questions do you } \\
\text { have? } \\
\text { After listening to } \\
\text { you, I think we also } \\
\text { need to talk about }\end{array}$ & & \\
\hline Demo-back & Practice & $\begin{array}{l}\text { What parts of your } \\
\text { child's care have you } \\
\text { practiced here in } \\
\text { preparing for going } \\
\text { home? } \\
\text { (Review teaching } \\
\text { checklist to assure all } \\
\text { topics have been } \\
\text { covered.) }\end{array}$ & $\begin{array}{l}\text { [ ] Demonstrates skills } \\
\text { correctly } \\
\text { [ ] Needs guidance with } \\
\text { demonstration of skills } \\
\text { [ ] Unable to demonstrate } \\
\text { skills }\end{array}$ & $\begin{array}{l}\text { [ ] Provided positive } \\
\text { reinforcement } \\
\text { [ ] Provided } \\
\text { supplemental } \\
\text { information } \\
\text { [ ] Provided extensive } \\
\text { teaching } \\
\text { [ ] Corrected information } \\
\text { errors } \\
\text { [ ] Provided additional } \\
\text { resources }\end{array}$ \\
\hline $\begin{array}{l}\text { Self-regulation: } \\
\text { Monitoring Think- } \\
\text { forward }\end{array}$ & $\begin{array}{l}\text { Child } \\
\text { Development }\end{array}$ & $\begin{array}{l}\text { Many children behave } \\
\text { differently than usual } \\
\text { after they go home } \\
\text { from the hospital. } \\
\text { We like to talk to all of } \\
\text { our families about the } \\
\text { kinds of behaviors } \\
\text { parents can expect. } \\
\text { Sometimes children } \\
\text { regress, or act younger } \\
\text { again for a short time. } \\
\text { You know your child } \\
\text { best. How do you think } \\
\text { your child will be at } \\
\text { home? (provide } \\
\text { example based on } \\
\text { developmental level). } \\
\text { This kind of temporary } \\
\text { behavior is normal; kids } \\
\text { are resilient and you } \\
\text { should see }\end{array}$ & $\begin{array}{l}\text { [ ] Verbalizes correct } \\
\text { information } \\
\text { [ ] Incorrect/unsure about } \\
\text { information } \\
\text { [ ] No understanding of } \\
\text { information }\end{array}$ & \begin{tabular}{|l} 
[ ] Positive \\
reinforcement \\
[ ] Supplemental \\
information \\
[ ] Extensive teaching \\
[ ] Corrected information \\
errors \\
[ ] Provided additional \\
resources \\
[ ] Provided pamphlet on \\
age-specific behaviors
\end{tabular} \\
\hline
\end{tabular}




\begin{tabular}{|c|c|c|c|c|}
\hline & & $\begin{array}{l}\text { improvement over } \\
\text { time. Kids can act } \\
\text { younger for } 2-3 \text { weeks. } \\
\text { If you find the behavior } \\
\text { does not improve after } \\
\text { 2-3 weeks, you should } \\
\text { discuss it with your } \\
\text { nurse or doctor. } \\
\text { Here are some things } \\
\text { you can do to manage } \\
\text { your child's behavior }\end{array}$ & & \\
\hline $\begin{array}{l}\text { Self-regulation: } \\
\text { Monitoring Think- } \\
\text { Forward }\end{array}$ & Watching Child & $\begin{array}{l}\text { Let's talk about things } \\
\text { to watch for in the first } \\
\text { few days or weeks after } \\
\text { your child is home: } \\
\text { Tell me how you would } \\
\text { know if your child is not } \\
\text { doing well? } \\
\text { What will you/they } \\
\text { watch for? } \\
\text { What will you do to } \\
\text { keep track of these } \\
\text { things? } \\
\text { I want to be sure that } \\
\text { What are other changes } \\
\text { (problems) that would } \\
\text { like? } \\
\text { your doctor or nurse } \\
\text { when you go home } \\
\text { What made you bring } \\
\text { your child in? } \\
\text { Tell me what situations } \\
\text { would make you want } \\
\text { to call your nurse or } \\
\text { doctor? } \\
\text { child's health? }\end{array}$ & $\begin{array}{l}\text { [ ] Verbalizes correct } \\
\text { information } \\
\text { [ ] Incorrect/unsure about } \\
\text { information } \\
\text { [ ] No understanding of } \\
\text { information }\end{array}$ & $\begin{array}{l}\text { [ ] Positive } \\
\text { reinforcement } \\
\text { [ ] Supplemental } \\
\text { information } \\
\text { [ ] Extensive teaching } \\
\text { [ ] Corrected information } \\
\text { errors } \\
\text { [ ] Provided additional } \\
\text { resources }\end{array}$ \\
\hline
\end{tabular}




\begin{tabular}{|c|c|c|c|c|}
\hline & & $\begin{array}{l}\text { make you bring him/her } \\
\text { in? } \\
\text { Think about what } \\
\text { he/she looked like } \\
\text { when you brought } \\
\text { him/her in. That's what } \\
\text { you might want to } \\
\text { compare to in order to } \\
\text { know what to watch } \\
\text { for. }\end{array}$ & & \\
\hline $\begin{array}{l}\text { Self-Regulation: } \\
\text { Problem Solving } \\
\text { Think-Forward }\end{array}$ & Recovery & $\begin{array}{l}\text { Think for a few minutes } \\
\text { about your child going } \\
\text { home ... imagine how } \\
\text { you think it will go } \\
\text { Tell me about your } \\
\text { child's normal activities, } \\
\text { e.g., getting up, eating, } \\
\text { going to school or } \\
\text { daycare? How will these } \\
\text { activities be different } \\
\text { while recovering at } \\
\text { home? } \\
\text { What will your child } \\
\text { need help with at } \\
\text { home? } \\
\text { When do you plan to } \\
\text { send him/her back to } \\
\text { school? What is your } \\
\text { plan for day care, } \\
\text { sports, driving, school } \\
\text { notes, excuses } \\
\text { After listening to you, I } \\
\text { think we also need to } \\
\text { talk about }\end{array}$ & $\begin{array}{l}\text { [ ] Verbalizes correct } \\
\text { information } \\
\text { [ ] Incorrect/unsure about } \\
\text { information } \\
\text { [ ] No understanding of } \\
\text { information }\end{array}$ & \begin{tabular}{|l} 
[ ] Positive \\
reinforcement \\
[ ] Supplemental \\
information \\
[ ] Extensive teaching \\
[ ] Corrected information \\
errors \\
[ ] Provided additional \\
resources
\end{tabular} \\
\hline $\begin{array}{l}\text { Self-Regulation: } \\
\text { Problem Solving } \\
\text { Think-forward }\end{array}$ & $\begin{array}{l}\text { Family } \\
\text { Adjustments }\end{array}$ & $\begin{array}{l}\text { In taking your child } \\
\text { home from the } \\
\text { hospital, what } \\
\text { adjustments will you } \\
\text { make? } \\
\text { Have you thought about } \\
\text { changes you and your } \\
\text { family will have to make } \\
\text { for your other children, }\end{array}$ & $\begin{array}{l}\text { [ ] Vague or unrealistic } \\
\text { plans } \\
\text { [ ] No plan }\end{array}$ & $\begin{array}{l}\text { [ ] Provided validation of } \\
\text { plans } \\
\text { [ ] Worked with patient } \\
\text { to identify specific plan } \\
\text { (parent engaged in } \\
\text { planning) } \\
\text { [ ] Worked with patient } \\
\text { to identify specific plan }\end{array}$ \\
\hline
\end{tabular}




\begin{tabular}{|c|c|c|c|c|}
\hline & & $\begin{array}{l}\text { your job, and/or other } \\
\text { family members? } \\
\text { In the first few days at } \\
\text { home? } \\
\text { Long-term changes? } \\
\text { After listening to you, I } \\
\text { think we also need to } \\
\text { talk about }\end{array}$ & & \begin{tabular}{|l} 
(parent not engaged in \\
planning) \\
[ ] Reviewed options: \\
home health, ICM, social \\
service, other
\end{tabular} \\
\hline $\begin{array}{l}\text { Social Facilitation } \\
\text { Think-forward }\end{array}$ & Home Care & $\begin{array}{l}\text { Tell me about who will } \\
\text { care for your child at } \\
\text { home } \\
\text { Who lives with you? } \\
\text { When your child goes } \\
\text { home, who will be the } \\
\text { person (or people) who } \\
\text { take care of your child? } \\
\text { When you're not home, } \\
\text { who takes care of your } \\
\text { child? } \\
\text { There will be things that } \\
\text { other caregivers will } \\
\text { need to learn. How will } \\
\text { they learn them and } \\
\text { when? } \\
\text { After listening to you, I } \\
\text { think we also need to } \\
\text { talk about }\end{array}$ & $\begin{array}{l}\text { [ ] Specific plans identified } \\
\text { [ ] Partial plans identified } \\
\text { [ ] Vague or unrealistic } \\
\text { plans } \\
\text { [ ] No plan }\end{array}$ & $\begin{array}{l}\text { [ ] Provided } \\
\text { validation of plans } \\
\text { [ ] Worked with } \\
\text { parent to identify } \\
\text { specific plan- } \\
\text { parent engaged in } \\
\text { planning } \\
\text { [ ] Worked with } \\
\text { parent to identify } \\
\text { specific plan- } \\
\text { parent not engaged } \\
\text { in planning } \\
\text { [ ] Reviewed } \\
\text { options: home } \\
\text { health, ICM, social } \\
\text { service, other } \\
\text { [ ] Scheduled teaching } \\
\text { time and plan for other } \\
\text { caregivers }\end{array}$ \\
\hline $\begin{array}{l}\text { Social Facilitation } \\
\text { Think-Forward }\end{array}$ & Parent Support & $\begin{array}{l}\text { Some parents share } \\
\text { that managing their } \\
\text { child's care at home is } \\
\text { often stressful } \\
\text { Who will be able to } \\
\text { help you with } \\
\text { household activities } \\
\text { while you take care of } \\
\text { the child? } \\
\text { Have you identified } \\
\text { specific things for your } \\
\text { helpers to do? }\end{array}$ & $\begin{array}{l}\text { [ ] Specific plans identified } \\
\text { [ ] Partial plans } \\
\text { [ ] Vague or unrealistic } \\
\text { plans } \\
\text { [ ] No plan }\end{array}$ & $\begin{array}{l}\text { [ ] Provided validation of } \\
\text { plans } \\
\text { [ ] Worked with patient } \\
\text { to identify specific plan } \\
\text { (parent engaged in } \\
\text { planning) } \\
\text { [ ] Worked with patient } \\
\text { to identify specific plan } \\
\text { (parent not engaged in } \\
\text { planning) } \\
\text { [ ] Reviewed options: } \\
\text { home health, ICM, social } \\
\text { service, other }\end{array}$ \\
\hline
\end{tabular}




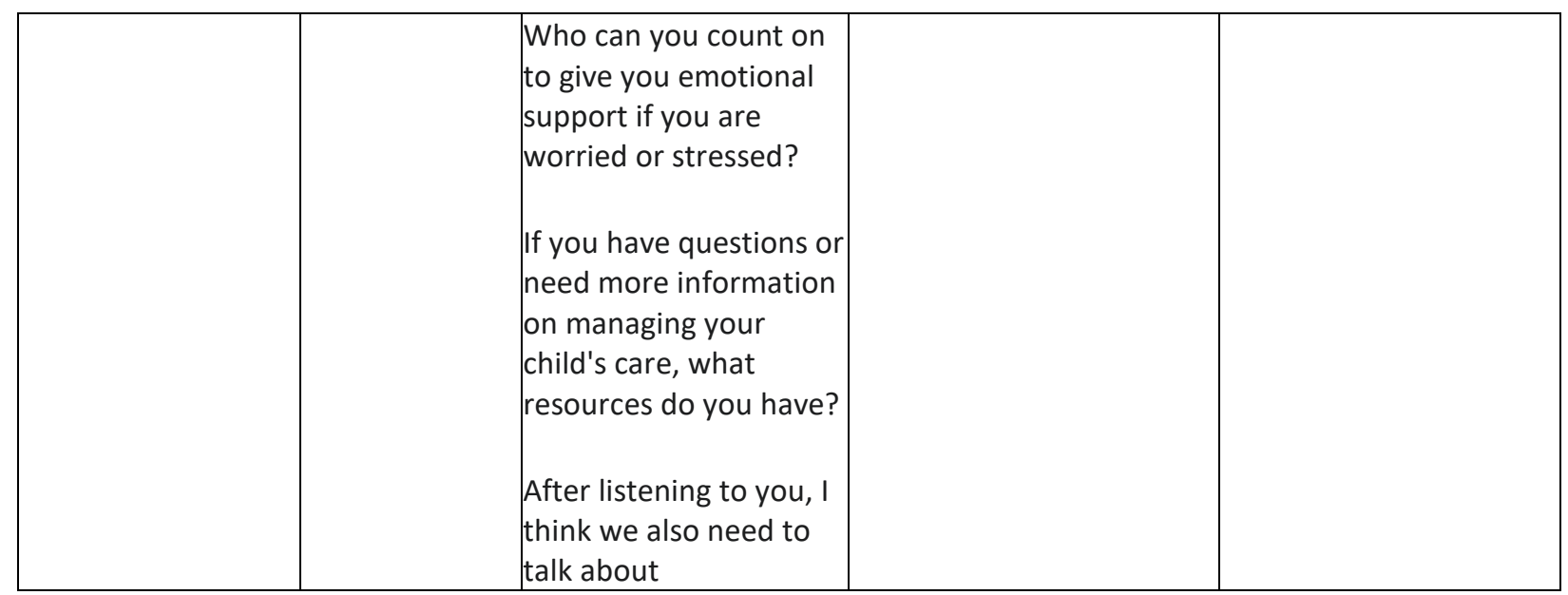

Note. ICM = interdisciplinary case management; IFSMT = Individual and Family Self-Management Theory; PRN = as needed; $\mathrm{RN}$ = registered nurse.

Tanner's Model of Clinical Judgment influenced the overall approach and structure of the FSMDPI. The assumption in creating the intervention was that an interaction or conversation guide was needed that (a) integrated the critical content areas as a "trigger" for the nurse, (b) structured the intervention for ease in documenting the nurse's interpretation and response to the situation, and (c) accommodated the nurse's ability to reflect on the parent's response and alter teaching. The stages of Tanner's Model of Clinical Judgment in Nursing were reflected in the three steps of data collection, interpretation, and nurse response included in the intervention. The team felt the "conversation guide" structure would facilitate the important aspects that the nurse needed to consider and would be flexible enough for the nurse to individualize the discharge preparation, interpret child and parent response, respond to their concerns, and adapt information or activities based on parents' understanding (see Table 1).

Teach-back had been implemented in our clinical setting for several years as a method of enhancing communication between healthcare providers and families (Kornburger et al., 2013). In the development of the intervention, "teach-back" was identified by the clinical nurses as central to their work and this discharge activity. For the purposes of intervention development, the Teach-Back method was expanded in two ways. The first was to add precision by specifying the labels for two strategies, talk-back and demo-back. Talk-back was added to imply that verbal responses were expected, and demo-back was added to clearly identify that a skill (e.g., dressing change) required more than parent statements of the procedure. Although the TeachBack method includes aspects of skill verification, we thought it best to be more specific about expectations. The second expansion was to add a think-forward approach to help the parent project to how the child's care would be managed in the home environment. Think-forward was identified as a strategy during the intervention development sessions. It was an outgrowth of discussions between nurses in the academic and practice partnership and was influenced by Tanner's Model (Tanner, 2006), which includes reflective practice. The think-forward addition was especially useful in helping the parents consider the self-management skills and abilities and the social facilitation they would need to effectively care for their child at home. While some questions used in past "teach-back" initiatives (Peter et al., 2015) addressed the future (e.g., How will you remember to weigh yourself every day? How will you remember to take 
your medication?), the think-forward strategy in this intervention was new. Think-forward created a way for parents to tell the nurse what they believed would be important aspects of their future circumstances at home and how they planned/prepared for the future. In essence, think-forward gave the nurse feedback on parent planning just as talk-back or demo-back gave the nurse feedback on knowledge and skills.

In the intervention, multiple teach-back strategies can be used in each domain. However, in Table 2, we indicated which of three strategies, talk-back, demo-back, or think-forward, was recommended as the primary teaching approach for each of the content domains of the FSMDPI. For example, a nurse might primarily use "think-forward" to help the parent anticipate and plan for care at home. But if the nurse found that the parent needed supplemental information, he or she would then use "talk-back" to assure the parents understood the additional information provided. Having specific language for these strategies identified in the intervention reflected the exact nature of how the nurse was to obtain feedback from the parent.

The iterative development of the intervention included the following steps: (a) developing the flow sheets for content, (b) having the content evaluated by a panel of clinical nurses who suggested revisions, (c) multiple large group sessions where the content and format was reviewed by team members, (d) relabeling the IFSMT process concepts in language that was more consistent with the terminology and work flow of the clinical nurse, and (e) creating a paper version of the intervention guide for field testing. The academic partners had previously developed the IFSMT (Ryan \& Sawin, 2009). In an iterative process that spanned several months and multiple meetings, the academic and clinical partners met jointly to develop the theoryguided intervention, content of the domains, questions, nurse assessment, and nurse actions. Following informal pilot testing with a small number of families assigned to several of the clinical nurses, the joint team revised the conversation guide. Table 2 is the team's working document of the conversation guide. Column 1 (IFSMT process) shows the IFSMT process categories aligned with the nine content domains to be covered in the interactive conversation (Column 2, Intervention category) and the primary strategy for delivering the intervention (talkback, demo-back, and think-forward). Column 3 (Prompt), Column 4 (RN assessment), and Column 5 (RN response) operationalize the intervention conversation. The key components are the nurse's prompt statements based on the content (Column 3); the nurse's interpretation of the parent's responses to the content probes about their knowledge, skills, and abilities (Column 4); and the nurse's response, or action, to validate, reinforce, or modify parents' knowledge, skills, and abilities (Column 5).

After responses to the prompt statements, the nurse could progress directly to interpretation or expand the conversation in each section as warranted based on the assessment of the parent response (After listening to you, I think we also need to talk about ...). The nurse's interpretation section addresses how well the parents are able to verbalize correct information, demonstrate the skill correctly, and generate a plan. Finally, for each of the intervention domains, the nurse indicated the response to the interpretation. Validation and positive reinforcement is to be given if the parent masters the domain. In contrast, if parents do not 
master the domain, the nurse could respond by using one or more strategies such as providing supplemental information, extensive teaching, correcting information errors, providing additional resources, or providing a pamphlet on age-specific behaviors. There is no required order for progressing through the conversation about each of the FSM-DPI domains. The nurse is free to use the order that meets the family's needs and priorities.

\section{Development of the Electronic Version}

Four clinical nurses from two general medical surgical units volunteered to field test the initial printed version of the intervention and provided feedback that the multiple-page document was too cumbersome to use. The team decided to convert the intervention to an electronic format on an $\mathrm{PAD}^{\circledR}$ platform. The intervention was transferred to the $\mathrm{iPAD}^{\circledR}$ by computer scientists at Marquette University with expertise in use of mobile devices for health applications. The electronic version is menu driven. Following password-protected login, a home screen is displayed that allows the nurse to see the menu with the nine domains on the left part of the screen and the content for the domain being discussed on the right. Color coding tells the nurse which domains are yet to be discussed (white for not started, yellow for partially complete, green for complete). The domain list remains visible, allowing the nurse to switch between domains if the conversation with the family transitions to a new content area. The structure of the FSM-DPI intervention on the i-PAD ${ }^{\circledR}$ remained the same (see Table 2), with each of the three columns from the paper version now visible vertically on the screen. There is a separate screen for each domain. The $\mathrm{iPAD}^{\circledR}$ can be connected via the Internet to a secure database for storage of data for evaluating intervention fidelity and outcomes. Retraining using the $\mathrm{PPAD}^{\circledR}$ version of the FSM-DPI was conducted. Feedback from the clinical nurses who had field tested the printed version indicated that the $\mathrm{PPAD}^{\circledR}$ version was much easier to use and facilitated their workflow in the discharge process.

\section{Implementation Challenges}

The main implementation challenge was the logistics of freeing the clinical nurses' time for an in-depth conversation with parents (and child if old enough) that was longer than the standard discharge teaching and required uninterrupted time. Other challenges that arose in preparing for clinical application were primarily operational, including infection control measures for using the $\mathrm{PPAD}^{\circledR}$ on clinical units, securing the $\mathrm{PAD}^{\circledR}$ between uses, and maintaining Internet connectivity. Integrating the intervention into an already busy practice requires strategies to facilitate the time needed for this intervention.

The practice partners identified multiple strategies to address these implementation challenges, including (a) "handing off assignments and pagers" to a charge nurse for the intervention implementation time, (b) planning for adequate time for the intervention in staffing assignments if the nurse is assigned a patient being discharged, (c) buddying with a fellow nurse to cover patient assignments during the discharge teaching session, and (d) fully engaging nurse leaders on the unit to support nurses in arranging time to conduct the interactive discharge conversation. 


\section{Discussion}

The development of the intervention generated multiple "lessons learned." The principal lesson was the power of the academic practice partnership, which created a milieu for "group think." Each of the academic practice partners participated in group think with different perspectives. The clinical nurse perspectives related to everyday clinical practice. The nurse leaders' perspectives highlighted nursing standard workflow on the units, existing systems, and expectations related to discharge. Finally, the academic nurses' perspectives focused on theory, measurement issues, the evidence on discharge preparation and self-management, and approaches to effective teaching.

The practice partners provided leadership throughout the development of the intervention about the feasibility of the content and conversation strategies. This input was central to each stage in the development of the final product. In the iterative discussions, the practice partners affirmed the relevance of the select components of self-management discharge preparation while identifying that some components were not typically addressed at discharge, for example, the child development domain. The clinical partners also transformed the language used in the conversation guide and led the discussions of how the intervention should be structured for easy flow. During the process, they reported a new appreciation of how complex it is to provide high-quality discharge preparation and were challenged to think differently about implementing an enhanced discharge model within the time constraints of typical day-ofdischarge care. Several clinical nurses reported that participating in developing this intervention led them to improve their practice; one nurse indicated that she thought being an active participant in this experience influenced her practice more than if change was implemented as a "typical" practice change.

\section{Conclusions}

A theory-based FSM-DPI was developed by nurses in a practice and academic partnership. The self-management and clinical judgment content was carefully translated to domains in an interactive conversation guide. The Teach-Back method was expanded to specifically include talk-back, demo-back, and think forward strategies. A field test by clinical nurses determined that using the printed version of the intervention was cumbersome and an electronic version was created to be tested in a large feasibility study. Operational issues in the clinical setting have been identified and strategies generated to address them. Implementation of the nursing intervention to enhance the pediatric discharge process is expected to improve the quality of discharge teaching, readiness for discharge, and outcomes in the postdischarge period by assuring that parents have the self-management knowledge, skills, and abilities needed to transition to home self-management after a child's hospitalization. The evaluation of this intervention has the potential to generate practice-based evidence for the intervention, the theoretical underpinnings, and the strategies of teach-back used. Evaluation of implementation experiences of nurses and patients is currently in progress. Further assessment of the content validity of the intervention through review by professional content experts and parents as recipients of care is indicated. Finally studies of outcomes attributable to the intervention are needed to determine utility for practice. 


\section{Clinical Resources}

- Agency for Healthcare Research and Quality: https://www.ahrq.gov/

- Family Caregiver Alliance. Hospital discharge planning: A guide for families and caregivers: https://www.caregiver.org/hospital-discharge-planning-guide-families-and-caregivers

- Project RED: http://www.bu.edu/fammed/projectred/components.html

- Society of Hospital Medicine. Better outcomes by optimizing safe transitions: http://www.hospitalmedicine.org/Web/Quality_Innovation/Implementation_Toolkits/Projec t_BOOST

\section{References:}

Auger, K. A., Kenyon, C. C., Feudtner, C., \& Davis, M. M. (2014). Pediatric hospital discharge interventions to reduce subsequent utilization: A systematic review. Journal of Hospital Medicine, 9(4), 251-260. doi:10.1002/jhm.2134

Bernstein, H. H., Spino, C., Baker, A., Slora, E. J., Touloukian, C. L., \& McCormick, M. C. (2002). Postpartum discharge: Do varying perceptions of readiness impact health outcomes? Ambulatory Pediatrics, 2(5), 388-395.

Berry, J. G., Agrawal, R., Cohen, E., \& Kuo, D. (2013). The landscape of medical care for children with medical complexity. Alexandria, VA and Overland Park, KS: Children's Hospital Association. Retrieved from https://www.childrenshospitals.org/issues-and-advocacy/children-with-medicalcomplexity/issue-briefs-and-reports/the-landscape-of-medical-care-for-children-with-medicalcomplexity

Berry, J. G., Blaine, K., Rogers, J., McBride, S., Schor, E., Birmingham, J., ... Feudtner, C. (2014). A framework of pediatric hospital discharge care informed by legislation, research, and practice. JAMA Pediatrics, 168(10), 955-962; quiz 965-956. doi:10.1001/jamapediatrics.2014.891

Berry, J. G., Hall, D. E., Kuo, D. Z., Cohen, E., Agrawal, R., Feudtner, C., ... Neff, J. (2011). Hospital utilization and characteristics of patients experiencing recurrent readmissions within children's hospitals. Journal of the American Medical Association, 305(7), 682-690. doi:10.1001/jama.2011.122

Conn, V. S., \& Groves, P. S. (2011). Protecting the power of interventions through proper reporting. Nursing Outlook, 59(6), 318-325. doi:10.1016/j.outlook.2011.06.003

Desai, A. D., Popalisky, J., Simon, T. D., \& Mangione-Smith, R. M. (2015). The effectiveness of familycentered transition processes from hospital settings to home: A review of the literature. Hospital Pediatrics, 5(4), 219-231. doi:10.1542/hpeds.2014-0097

Haney, M., \& Shepherd, J. (2013). Can teach-back reduce hospital readmissions? American Nurse Today, 9(3), 50-52.

Hansen, L. O., Greenwald, J. L., Budnitz, T., Howell, E., Halasyamani, L., Maynard, G., ... Williams, M.V. (2013). Project BOOST: Effectiveness of a multihospital effort to reduce rehospitalization. Journal of Hospital Medicine, 8(8), 421-427.

Howie-Esquivel, J., White, M., Carroll, M., \& Brinker, E. (2011). Teach-back is an effective strategy for educating older heart failure patients. Journal of Cardiac Failure, 17(8, Suppl.), S103. doi:10.1016/i.cardfail.2011.06.345 
Kazer, M. W., Bailey, D. E., \& Whittermore, R. (2010). Out of the black box: Expansion of a theory-based intervention to self-manage the uncertainty associated with active surveillance (AS) for prostate cancer. Research and Theory for Nursing Practice, 24(2), 101-112.

Kemp, E. C., Floyd, M. R., McCord-Duncan, E., \& Lang, F. (2008). Patients prefer the method of "tell backcollaborative inquiry" to assess understanding of medical information. Journal of the American Board of Family Medicine, 21(1), 24-30. doi:10.3122/jabfm.2008.01.070093

Kornburger, C., Gibson, C., Sadowski, S., Maletta, K., \& Klingbeil, C. (2013). Using "teach-back" to promote a safe transition from hospital to home: An evidence-based approach to improving the discharge process. Journal of Pediatric Nursing, 28(3), 282-291. doi:10.1016/i.pedn.2012.10.007

Lerret, S. M., \& Weiss, M. E. (2011). How ready are they? Parents of pediatric solid organ transplant recipients and the transition from hospital to home following transplant. Pediatric Transplantation, 15(6), 606-616. doi:10.1111/i.1399-3046.2011.01536.x

Lerret, S. M., Weiss, M. E., Stendahl, G., Chapman, S., Neighbors, K., Amsden, K., ... Alonso, E. M. (2014). Transition from hospital to home following pediatric solid organ transplant: Qualitative findings of parent experience. Pediatric Transplantation, 18(5), 527-537. doi:10.1111/petr.12269

National Quality Forum. (2009, March). Health literacy: A linchpin in achieving national goals for health and healthcare. National Quality Forum Issue Brief, No. 13, 1-5.

Peter, D., Robinson, P., Jordan, M., Lawrence, S., Casey, K., \& Salas-Lopez, D. (2015). Reducing readmissions using teach-back: Enhancing patient and family education. Journal of Nursing Administration, 45(1), 35-42. doi:10.1097/NNA.0000000000000155

Ryan, P., \& Sawin, K. J. (2009). The Individual and Family Self-Management Theory: Background and perspectives on context, process, and outcomes. Nursing Outlook, 57(4), 217-225, e216. doi:10.1016/i.outlook.2008.10.004

Ryan, P. A., \& Sawin, K. J. (2014). Individual and family self-management theory [Revised Figure]. Retrieved from http://www4.uwm.edu/nursing/about/centers-institutes/selfmanagement/theory.cfm.

Samuels-Kalow, M. E., Stack, A. M., \& Porter, S. C. (2012). Effective discharge communication in the emergency department. Annals of Emergency Medicine, 60, 152-159.

Schillinger, D., Piette, J., Grumbach, K., Wang, F., Wilson, C., Daher, C., ... Bindman, A. B. (2003). Closing the loop: Physician communication with diabetic patients who have low health literacy. Archives of Internal Medicine, 13(1), 83-90.

Sidani, S., \& Braden, C. J. (2011). Design, evaluation, and translation of nursing interventions. Oxford, UK: Wiley-Blackwell.

Slater, B., Dalawari, P., \& Huang, Y. (2013). Does the teach-back method increase patient recall of discharge instructions in the emergency department? Annals of Emergency Medicine, 62(4, Suppl.), S20. doi:10.1016/j.annemergmed.2013.07.335

Tanner, C. A. (2006). Thinking like a nurse: A research-based model of clinical judgment in nursing. Journal of Nursing Education, 45(6), 204-211.

Weiss, M., Bobay, K. L., Bahr, S. J., Costa, L., Hughes, R. G., \& Holland, D. E. (2015). A model for hospital discharge preparation: From case management to care transition. Journal of Nursing Administration, 45(12), 606-614. doi:10.1097/NNA.0000000000000273

Weiss, M., Johnson, N. L., Malin, S., Jerofke, T., Lang, C., \& Sherburne, E. (2008). Readiness for discharge in parents of hospitalized children. Journal of Pediatric Nursing, 23(4), 282-295. doi:10.1016/i.pedn.2007.10.005

Weiss, M., Ryan, P., \& Lokken, L. (2006). Validity and reliability of the Perceived Readiness for Discharge After Birth Scale. Journal of Obstetric Gynecologic and Neonatal Nurses, 35(1), 34-45. 
White, M., Garbez, R., Carroll, M., Brinker, E., \& Howie-Esquivel, J. (2013). Is "teach-back" associated with knowledge retention and hospital readmission in hospitalized heart failure patients? Journal of Cardiovascular Nursing, 28(2), 137-146. doi:10.1097/JCN.0b013e31824987bd 